\title{
Factors Affecting Customer Decision on Using Tabung Haji Service Center in Malaysia
}

\author{
Abbas Paliket \\ Faculty of Management of Science, Yala Rajabhat University \\ abbas.p@yru.ac.th
}

\begin{abstract}
The objective of this research was to examine the factors affecting the decision of choosing the Tabung Haji Service center in Malaysia. Questionnaires were used for data collection. The sample groups were individuals living in the state of Kedah, Malaysia. The statistics used for data analysis were frequency, percentage, mean $(\overline{\mathrm{X}})$, standard deviation (SD), and comparison test (t). -test) and one-way ANOVA analysis. It found most of them were male who are under 25 years old. They were single and hold undergraduate education. Their monthly average income was between RM1,201- RM2,000. The overall results of marketing mix factors were at a high level $(\overline{\mathrm{X}}=4.301$ S.D. $=0.493)$. When sorted by the importance that the process aspect and the people aspect, they were at the most important level with the average score of 4.6584 .555 and standard deviation 0.4350 .445 respectively. The physical evidence, price, promotion, place, and product were at a high level. The mean score was $4.246,4.236,4.187,4.133,4.095$ and the standard deviation were at $0.95,0.363,0.549,0.580,0.569,0.514$, respectively. There were significant influence of age, educational level, and monthly average income on the market mix factors of customers' decision to selecting Tabung Haji Service Center in Malaysia at a statistically significant level of 0.05 .
\end{abstract}

Keywords

Customer Behavior, Marketing Mix, Tabung Haji, Islamic Finance

Article Received: 10 August 2020, Revised: 25 October 2020, Accepted: 18 November 2020

\section{Introduction}

Islamic finance is based on a few simple rules which must adhere to justice is a financial system under the framework of Islam or Shariah principles with the fundamental principles of sharing risk and profit. Financial activities are prohibited on interest (Riba '), uncertainty (Gharar), and gambling (Maysr) [1] [2] [3]. The main Shariah which is called Fiqh Muamalat, is based on the Quran and Sunni. It can also be cited from other secondary sources of Islamic law, such as the opinions agreed upon by Islamic scholars (Ijma's), comparisons (Qiyas) and personal reasoning (Ijtihad) [3]. The establishment of Islamic financial institutions took place in the Indian subcontinent in the 1940 s, which began with saving and lending interest free. It was followed by collecting financial for business organizations. One of the important pioneers in Islamic finance is to establish a pilgrimage fund committee in Malaysia in order to save money for expenses for the Hajj ceremony in Saudi Arabia [4]. The Islamic finance grows continuously. According to the report of Islamic Finance Development in 2019, Islamic finance industry's assets increased up to US \$ 2.5 trillion in 2018 from US\$2.4 trillion in 2017, which are up to 3 percent in Iran, Saudi Arabia and Malaysia. These countries are considered the largest grown country among 61 counties. Morocco, Cyprus and Ethiopia are the fastest grown country which the combined assets are more than US $\$ 500$ billion [5]. The Islamic finance industry in Malaysia is characterized by a comprehensive market component from Islamic banking takaful, Islamic money market, and Islamic investment market. Malaysia is furthermore the main driving country in sukuk and bonds (issuance), with a market share of $51.0 \%$ and $36.2 \%$ respectively. At the end of 2017 in the banking sector, Malaysia possesses the combined assets of
USD204.4 billion and is third place in the world after Iran and Saudi Arabia. Moreover, Malaysia remain a leader in the Islamic wealth management industry that is the key for Islamic funds worldwide with USD28.3 billion (36.5\% global share) [6].

Tabung Haji (TH) is an agency established by the Malaysian government in 1963, under the Tabung Haji Act 1963 (Act 535) which is intended to facilitate the Muslims of Malaysia in performing Hajj. Tabung Haji currently manages more than RM25 billion in deposits (2016) both domestically and internationally by investing in a number of sectors such as Indonesia's plantation, Islamic Finance Information Technology, Oil and gas, services, substantial estate, and construction sectors in the UK and Australia with more than RM3 billion (2016) of net profit, which can provide a return to depositors. The Hajj Enterprise Fund is recognized around the world as an example of Hajj Management and financial services. It has more than 9 million depositors out of 125 locations with 6,000 service points nationwide.There is additionally a Hajj office in Jeddah, Saudi Arabia under the control of Consulate General of Malaysia [7]. TH is the one and only institution that enable Muslim to gradually save their money to perform the pilgrimage when their time comes. Muslims also save their money in TH for investment purpose as $\mathrm{TH}$ is guaranteed by the government that all of the savings will be run according to Shari'ah.

In order for the Islamic financial sector to be competitive and to ensure the vision of making Malaysia as global financial hub, it is important to have adequate advance planning in this area. Therefore, during the Seminar on the Ten-Year Master Plan for the Islamic financial services industry organized by the Islamic Development Bank (IDB) and the Islamic Financial Services Board (IFSB), the Malaysian Government has initiated the drafting of the ten years master plan for the Islamic financial services industry. 
Two important areas of focus namely, building institutional capacity and the developmentof the supporting financial infrastructure has been identified as the strategic element in the development of a progressive Islamic financial services [4].

Customers of today are more service-minded and they tend to expect better services from financial institutions. In order for $\mathrm{TH}$ to compete successfully with financial institue, $\mathrm{TH}$ must give extremely high consideration to their primary customers. Whenever TH offer any product or service, its success depends upon the customer satisfaction and customer behavior towards that product or service. This study examines factors affecting customers'decision on selecting Tabung Haji Service Center in Malaysia.

\section{Research Objectives}

The objectives of this research article were to examines factors affecting customers' decision on selecting Tabung Haji Service Center in Malaysi

\section{Research Conceptual Framework}

Customer behavior theory and theory of marketing mix (7P's) [8][9] that have been adopted in the conceptual framework. It can be summarized as a conceptual framework comprising various factors that affects the decision on selecting the Tabung Haji Service center in Malaysia as shown in Figure 1.

\begin{tabular}{|c|c|}
\hline Independent variable & dependent variable \\
\hline Geographic & Marketing Mix Factor (7P's) \\
\hline Characteristic & -Product \\
\hline -Gender & -Price \\
\hline -Age & -Place \\
\hline -Status & -Promotion \\
\hline -Education & -People \\
\hline -Occupation & -Process \\
\hline - Monthly average income & -Physical Evidence \\
\hline
\end{tabular}

Fig.1 A Conceptual Framwork

\section{Research Hypotheses}

There is a significant influence of the independent variables on dependent variable. In this study there are six hypotheses;

$\mathrm{H} 1$ : There is a significant influence of gender on marketing mix factors for customers' decision on selecting Tabung Haji Service Center in Malaysia

$\mathrm{H} 2$ : There is a significant influence of age on marketing mix factors for customers' decision on selecting Tabung Haji Service Center in Malaysia

$\mathrm{H} 3$ : There is a significant influence of status on marketing mix factors for customers' decision on selecting Tabung Haji Service Center in Malaysia

H4 : There is a significant influence of education on marketing mix factors for customers' decision on selecting Tabung Haji Service Center in Malaysia

H5 : There is a significant influence of occupation on marketing mix factors for customers' decision on selecting Tabung Haji Service Center in Malaysia

H6 : There is a significant influence of montly average income on marketing mix factors for customers' decision on selecting Tabung Haji Service Center in Malaysia

\section{Research Methods}

\section{A. Samples and population}

The population in this study was the customers of the Tabung Haji Service Center in Kedah State, Malaysia. The samples comprised the people who have experienced in using Tabung Hayi Service Center. The researcher defined the samples as a case where the exact population is unknown at the $95 \%$ of reliability level. The ideal samples were 385 samples with an additional $4 \%$ of backup data was collected. The total samples would be 400 samples in order to reduce errors if there were incomplete questionnaires. The probability principle was used to divide the samples employing the coincidental sampling method [10]. The reason for selecting users of the Tabung Haji Service Center in Kedah State, Malaysia is that the state is near the border of Thailand. It has a similar social context and convenient access to information because the researcher is familiar with the context.

\section{B. Research Tool}

In this study, questionnaires were used. It was developed within the framework of objectives and can be divided into 3 parts as follows.

Part 1 Demographic data including gender, age, education, occupation, average monthly income.

Part 2 Marketing Mix Factors affecting decision on using the Tabung Haji Service Center in Kedah State, Malaysia. It is a questionnaire for estimating 5 levels with scores in each level as follows:

5 points mean that it is most important in choosing the service.

4 points mean that it is very important in choosing the service.

3 points mean that it is moderate important in choosing the service.

2 points mean that it is low important in choosing the service.

1 point means that it is the lowest important for the service.

Part 3 Recommendations There is a validity test under consideration by experts. Testing the reliability of 30 questionnaires showed that Cronbach's Alpha Coefficient was at 0.833 with a high level of reliability [11].

\section{Data Analysis}

Descriptive statistics are analyzed by using Frequency, Percentage, Mean, Standard, and deviation-SD to measure the distribution of data and to describe demographic data and the behavior of the respondents using the Tabung Haji Service Center in Kedah State, Malaysia. By interpreting Mean values, it will be interpreted as follows [12].

The average means score of 4.51-5.00 refers to the highest importance.

The average means score of 3.51-4.50 refers to the a high importance.

The average means score of 2.51-3.50 refers to the moderate importance.

The average means score of 1.51-2.50 refers to the low importance. 
The average means score of $1.00-1.50$ refers to the lowest importance.

Inferential statistics are used to test the hypothesis. The statistics used were a t-test, ANOVA analysis using F-test (One-way ANOVA).

\section{Result}

Demographic data of respondents found that most of them were male $(63.0 \%)$, under 25 years old $(45.8 \%)$, single $(65.8 \%)$, hold bachelor degree $(51.3 \%)$, students $(33.3 \%)$, gained monthly average income between RM1,201RM2,000 (33.8\%).

Table 1 Mean and standard deviation o the level of significant of marketing mix factors influencing for customers' decision on selecting Tabung Haji Service Center in Malaysia

\begin{tabular}{lcccc}
\hline \multicolumn{1}{c}{ Marketing Mix Factors } & $\bar{X}$ & S.D. & Level of Importance & Rank \\
\hline Product & 4.095 & 0.514 & important & 7 \\
\hline Price & 4.236 & 0.549 & important & 4 \\
\hline Place & 4.133 & 0.569 & important & 6 \\
\hline Promotion & 4.187 & 0.580 & important & 5 \\
\hline People & 4.555 & 0.445 & Very important & 2 \\
\hline Process & 4.658 & 0.435 & Very important & 1 \\
\hline Physical Evidence & 4.246 & 0.363 & important & 3 \\
\hline Total of Marketing Mix Factors & $\mathbf{4 . 3 0 1}$ & $\mathbf{0 . 4 9 3}$ & important & - \\
\hline
\end{tabular}

From Table 1, the results show that the consumers value the overall marketing mix factor at a high level. The mean score was 4.301 with a standard deviation of 0.493 . Sorting by importance, process aspect was the highest $(\square=4.658 \mathrm{SD}$ $=0.435)$, followed by personnel which is at the highest level of importance. $(\square=4.555 \mathrm{SD}=0.445)$. The physical characteristics were at a high level $(\square=4.246 \mathrm{SD}=0.363)$. The price was at a high level $(\square=4.236 \mathrm{SD}=0.549)$. The market promotion was at the high level ( $\square=4.187 \mathrm{SD}=$ 0.580). The distribution channel was at high level ( $\square=$ $4.133 \mathrm{SD}=0.569)$ and product was at high level $(\square=4.095$ $\mathrm{SD}=0.514)$, respectively.

A.The finding of Hypothesis Test

$\mathrm{H} 1$ : There is a significant influence of gender on marketing mix factors for customers' decision on selecting Tabung Haji Service Center in Malaysia

Table 2: Comparison of mean for marketing mix influence customer's decision on selecting Tabung Haji service center in Malaysia classified by gender (independent-samples ttest)

\begin{tabular}{lccccc}
\hline Gender & Mean & Std. Deviation & $\mathrm{t}$ & Significant & Result \\
\hline Male & 4.3056 & 0.268 & 0.017 & & \\
\cline { 1 - 3 } Female & 4.2956 & 0.311 & 0.025 & 0.063 & not sig. \\
\hline
\end{tabular}

Notes: ${ }^{*}$ statistical significant level of 0.05
Based on table 2, the result shows that the significant influencing for customer's decision on selecting Tabung Haji service center in Malaysia was 0.063 which were greater than 0.05 .

$\mathrm{H} 2$ : There is a significant influence of age on marketing mix factors for customers' decision on selecting Tabung Haji Service Center in Malaysia

Table 3: Comparison of mean for marketing mix influence customer's decision on selecting Tabung Haji service center in Malaysia classified by age (One-Way ANOVA)

\begin{tabular}{lcccccc}
\hline & Sum of Squares & df & Mean Square & F & Significant & Result \\
\hline Between Groups & 1.055 & 4 & 0.264 & 3.337 & 0.011 & sig. \\
\hline Within Groups & 31.212 & 395 & 0.079 & & & \\
\hline Total & 32.267 & 399 & & & & \\
\hline Notes : * & statistical significant level of 0.05 & & & & &
\end{tabular}

In the table 3, the result shows that the significant effect of age on marketing mix factors for customer's decision on selecting Tabung Haji service center in Malaysia was 0.011 which were lesser than 0.05 . Therefore, the researcher accepted H2. The LSD (Least Significant Difference) method can be used to test samples between groups that show differences in mean values. The results show that there are three groups had a significant difference between those with the age less 25 years old and those with the age between 36-45 years old (mean difference $=0.132$, sig. $=$ 0.005 ) then, the age between 26-35 years old and the age between 36-45 years old (mean difference $=0.168$, sig. $=$ 0.001 ) finally, the age between $36-45$ years old and the age between 46-55 years old (mean difference $=-0.219$, sig. $=$ 0.021 ). The mean difference is significant at the 0.05 level.

H3 : There is a significant influence of marital status on marketing mix factors for customers' decision on selecting Tabung Haji Service Center in Malaysia

Table 4: Comparison of mean for marketing mix influence customer's decision on selecting Tabung Haji service center in Malaysia classified by marital status (One-Way ANOVA)

\begin{tabular}{lcccccr}
\hline & Sum of Squares & df & Mean Square & F & Significant & Result \\
\hline Between Groups & 0.462 & 2 & 0.231 & 2.881 & 0.057 & not sig. \\
\hline Within Groups & 31.805 & 397 & 0.080 & & & \\
\hline Total & 32.267 & 399 & & & & \\
\hline Notes : * statistical significant level of 0.05 & & & & &
\end{tabular}

According to the table 4, the result shows that the significant influence of marital status on marketing mix factors for customer's decision on selecting Tabung Haji service center in Malaysia was 0.057 which were greater than 0.05 . Therefore, the researcher rejected H3. The LSD (Least Significant Difference) method can be used to test samples between groups that show differences in mean values. The results show that a significant difference between single and married (mean difference $=0.069$, sig. $=0.0021$ ) The mean difference is significant at the 0.05 level.

H4 : There is a significant effect of level of education on marketing mix factors for customer's decision on selecting Tabung Haji service center in Malaysia

Table 5: Comparison of mean for marketing mix influence customer's decision on selecting Tabung Haji service center in Malaysia classified by level of education (One-Way ANOVA)

\begin{tabular}{lcccccc}
\hline & Sum of Squares & df & Mean Square & F & Significant & Result \\
\hline Between Groups & 2.203 & 4 & 0.551 & 7.238 & 0.000 & sig. \\
\hline Within Groups & 30.063 & 395 & 0.076 & & & \\
\hline Total & 32.267 & 399 & & & & \\
\hline Notes : * statistical significant level of 0.05 & & & & &
\end{tabular}


According to the table 5, the result shows that the significant influence of level of education on marketing mix factors for customer's decision on selecting Tabung Haji service center in Malaysia was 0.000 which were lesser than 0.05 . Therefore, the researcher accepted H4. The LSD (Least Significant Difference) method can be used to test samples between groups that show differences in mean values. The results show that there are five groups had a significant difference between those with primary school and those with more than master degree (mean difference $=0.302$, sig.=0.007) second, between high school and more than master degree (mean difference $=0.225$, sig. $=0.007$ ) third, the level of education between diploma and bachelor degree (mean difference $=0.072$, sig. $=0.022$ ) forth, the level of education between diploma and more than master degree (mean difference $=0.241$, sig. $=0.000$ ) finally, the level of education between bachelor degree and more than master degree $($ mean difference $=0.168$, sig. $=0.000)$. The mean difference is significant at the 0.05 level.

H5 : There is a significant influence of occupation on marketing mix factors for customer's decision on selecting Tabung Haji service center in Malaysia

Table 6: Comparison of mean for marketing mix influence customer's decision to selecting Tabung Haji service center in Malaysia classified by occupation (One-Way ANOVA)

\begin{tabular}{lcccccc}
\hline & Sum of Squares & df & Mean Square & F & Significant & Result \\
\hline Between Groups & 2.203 & 4 & 0.551 & 7.238 & 0.000 & sig. \\
\hline Within Groups & 30.063 & 395 & 0.076 & & & \\
\hline Total & 32.267 & 399 & & & & \\
\hline
\end{tabular}

Notes : * statistical significant level of 0.05

Based on table 5, the result shows that the significant influence of occupation on marketing mix factors for customer's decision on selecting Tabung Haji service center in Malaysia was 0.000 which were lesser than 0.05 . Therefore, the researcher accepted H5. The LSD (Least Significant Difference) method can be used to test samples between groups that show differences in mean values. The results show that there are four groups had a significant difference between those with housewife and those with self-employed (mean difference $=-0.153$, sig. $=0.021$ ) second, occupation between goverment staff and selfemployed (mean difference $=-0.133$, sig. $=0.008)$ third, occupation between self-employed and pensioner (mean difference $=0.163$, sig. $=0.044$ ) finally, occupation between self-employed and student (mean difference $=0.134$, sig. $=$ 0.007). The mean difference is significant at the 0.05 level.

H6 : There is a significant influence of average montly income on marketing mix factors for customer's decision to selecting Tabung Haji service center in Malaysia

Table 7: Comparison of mean for marketing mix influencing customer's decision to selecting Tabung Haji service center in Malaysia classified by monthly average income (One-Way ANOVA)

\begin{tabular}{lcccccc}
\hline & Sum of Squares & df & Mean Square & F & Significant & Result \\
\hline Between Groups & 1.707 & 4 & 0.427 & 5.516 & 0.000 & sig. \\
\hline Within Groups & 30.560 & 395 & 0.077 & & & \\
\hline Total & 32.267 & 399 & & & & \\
\hline
\end{tabular}

Notes : * statistical significant level of 0.05

Table 7 show the result of the significant influence of average monthly income on marketing mix factors for customer' decision to selecting Tabung Haji service center in Malaysia was 0.000 which were lesser than 0.05 . Therefore, the researcher accepted H6. The LSD (Least Significant Difference) method can be used to test samples between groups that show differences in mean values. The results show that there are five groups had a significant difference between those with average monthly income less than RM1,500 and those with average monthly income between RM1,501 - RM3,000 (mean difference = 0.894, sig.= 0.012) second, average monthly income less than RM1,500 and average monthly income between RM3,501 RM4,500 (mean difference $=0.173$, sig. $=0.000$ ) third, average monthly income less than RM1,500 and average monthly income between RM4,501 - RM6,000 (mean difference $=0.156$, sig. $=0.001)$ forth, average monthly income between RM3,001 - RM4,500 and average monthly income more than RM6,000 (mean difference $=-0.155$, sig. $=0.005$ ) finally, average monthly income between RM4,501 - RM6,000 and average monthly income more than RM6,000 (mean difference $=-0.139$, sig. $=0.016$ ) The mean difference is significant at the 0.05 level.

\section{Discussion}

The result of this study shows that the customers value the overall marketing mix factor at a high level, this finding is similar to previous studies which found that the importance of marketing mix that affects customer selecting decision at important level [13][14][15]. It is noteworthy that the product factor, respondents put their final priorities when compared to other marketing mixes, but still at a very important level. Researcher see that because Tabung Haji only has one financial product that is savings (wadi'ah yaddhamanah) therefore customer don't have the wide variety of product choices.

The respondents focused on the process and people factors at very important level, this finding is similar to previous studies which found that process and people factors had a significantly positive relationship with customer satisfaction [16][17]. The process factor, customers focus on easy, smooth, convenient and fast online service [16] as well as accurate, fastly service that can respond to customer needs, safety, reliable and trustworthy.

While, people factor is one factor affecting on service quality, where respondents seeing that people should be courteous, friendly, service enthusiasm, clear advice and answering and be honest and trustworthy. This finding is similar to previous studies which found that people factors influencing on decision to use Islamic banking, which employees are essential to understand the importance of service, fastly services is one of the most important tools for employees as well as the customer-friendly service [18]. This is also consistent with previous research which found that customer relationship influences customers to frequent Tabung Haji is employee commitment (76.2\%), which employee should be polite when dealing with customer, especially during over-the-counter financial services [19].

Hypothesis testing shows that there is a significant influence of age, level of education, occupation and monthly average income on marketing mix factors for customer's decision to selecting Tabung Haji Service Center in Malaysia, whereas there is no significant influence of gender and marital status 
on marketing mix factors for customer's decision to selecting Tabung Haji Service Center in Malaysia

These findings

This finding rejected $\mathrm{H} 1$, that is similar to previous studies which found that there was no significant difference between males and females for customer satisfaction and that gender and ethnicity had significant [20][21]. One more previous study similar to this finding which found that there was no significant different between gender with marketing mix affecting to use of Government Savings Bank services in Pranburi District, Prachuap Khiri Khan Province, Thailand [22]. While, the significant influence of age on marketing mix factors for customer's decision to selecting Tabung Haji Service Center in Malaysia was 0.011 which were lesser than 0.05 . Therefore, the researcher accepted H2. In services, age relates significantly and negatively; signifying that the older customers as compared to their younger counterpart, hold less favorable opinion about the reliability as well as three other service quality constructs, personal interactions, functional quality, outcome quality and overall service quality [23].

From H4, there is a significant influence of education level on marketing mix factors for customer's decision to selecting Tabung Haji Service Center in Malaysia, the researcher accepted $\mathrm{H} 4$. This finding is similar to previous studies which found that there is a significant difference between level of education and customer satisfaction. Besides that, the respondents' levels of education had different opinions of customer satisfaction related to the services provided [20][24].

Hypothesis testing, the result found that the researcher accepted H4 that mean there is a significant influence of occupation on marketing mix factors for customer's decision to selecting Tabung Haji Service Center in Malaysia. This finding is similar to previous studies which found that there was significant different between occupation and customer adoption and customer satisfaction of bank service [13][14][25]. In addition, knowledge of customers' occupation can help marketers in devising strategies capable of more effectively delivering services to the specific needs of customers belonging to different occupation groups [23]. Finally, this finding accepted H6, this finding is similar to previous studies which found that there was significant influence of the Decision in Choosing bank's product [26][27][28]. It concludes, a person's economic opportunity will affect the products and services they decide to buy or selecting.

\section{Recommendations}

\section{A. Recommendations for Practices}

1. The findings of the study would help marketeer to focus on the elements needed to be developed to have a significant influence on customers' decision on selecting Islamic or non-Islamic financial institute.

2. Tabung Haji could use this finding for further research to understand customer behavior towards their organization, which will provide them the opportunity to foster their marketing activities to survive in the competition.

\section{B. Recommendations for Further Research}

1. The study is limited to Kedah state the results may be different in various state of Malaysia so to enhance the generalization of the findings it is proposed to conduct this study in different state of Malaysia.

2. To obtain qualitative information Therefore, qualitative research methods should be obtained for future studies such as in-depth interviews, focus group observations and so on.

3. Other Variant such as customer loyal, customer satisfaction, customer relationship management should be obtain for future studies.

4. Internet-banking and social banking related to customer behavior is an interesting issue should be studied for the Islamic financial industry.

\section{Conclusion}

The result and findings of this research to guide the development of marketing mix factor influence customer's decision on selecting Tabung Haji Service Center as well as demographic-driven marketing to target and attract customers efficiently. This study is the first to investigate demographic effect on customer decision to use Tabung Haji in Malaysia. The findings can contribute to future research on customer decision and customer behavior, and guide Malaysia's Islamic or non-Islamic Financial institute management towards more effective marketing and service provision. post hoc tests to determine demographic subgroup differences in Tabung Haji service quality perceptions across gender, age, status, occupation, education and monthly average income. Results revealed significant differences in various aspects of perceptions of Islamic financial institute service quality for all demographic variables. In the context of the Islamic or non-Islamic, bank or non-bank, the findings of this study could contribute in segmenting Malaysian's finance service consumers.

\section{References}

[1] Malaysia World's Islamic Finance Marketplace, "Introduction to Islamic Finance", Retrieved on 1st January 2021, from http://www.mifc.com/index.php?ch=ch_kc _definitions\&pg=pg_kcdf_overview\&ac $=$ 293.

[2] Mabid Ali Al-Jarhi, "An economic theory of Islamic finance", International Journal of Islamic Finance Vol.9, No.2, pp.117132, 2017.

[3] Purnomo M Antaraa , Rosidah Musab ,
Faridah Hassanc, "Bridging Islamic
Financial Literacy and Halal Literacy: The
Way Forward in Halal Ecosystem", 
Procedia Economics and Finance 37, pp196 - 202, 2016.

[4] Mohamad Akram Laldin, "Islamic financial system: the Malaysian experience and the way forward", Humanomics: The International Journal of Systems and Ethics, Vol.24, No.3, pp. 217-238, 2008.

[5] Islamic Finance Development Report 2019, Retrieved on 1st January 2021, from https://icd-

ps.org/uploads/files/IFDI\%202019\%20DE F\%20digital1574605094_7214.pdf.

[6] Malaysia World's Islamic Finance Marketplace, "Islamic Finance in Asia: Reaching New Heights ", Retrieved on 1st January 2021, from http://www.mifc.com/index.php?ch=28\&p $\mathrm{g}=72 \& \mathrm{ac}=189 \& \mathrm{bb}=$ uploadpdf

[7] Tabung Haji. "Corporate Profile" Retrieved on 1st January 2021, from https://www.tabunghaji.gov.my/index.php/ en/corporate/corporate-information/aboutus

[8] Armstrong, G., Adam, S., Denize, S., and Kotler, P., "Principles of Marketing", 5th ed., Sydney: Pearson Education, 2012.

[9] Kotler,P., \& Armstrong, G., "Principles of Marketing", 15th ed., Sydney: Pearson Prentice Hall, 2013.

[10] Thanin Silpcharu, "Research and Statistical Analysis of SPSS and AMOS Data", Bangkok: SR Printing Mass Products, 2017.

[11] Cronbach, L. J., "Essentials of Psychological testing", 5th ed., New York: Harper Collins Publishers, 1990.

[12] Pimentel, J. L., "A Note on the Usage of Likert Scaling for Research Data Analysis", USM R\&D Journal, Vol 18, No.2, pp.09-112, 2010.

[13] Somkit Yakaen and Pornpen Homboonma, "Factor Influecing the adoption of Goverment Saving Bank's Service in Urban and rural Areas in Lampang Province", Journal of Business, Economics and Communications: BEC Journal, Vol.11, No.2, pp.60-171, 2016.
[14] Wasinee Sateanrakarn, "Factors Affecting Consumer Choice Of Services By Bangkok Bank Public Company Limited", Bangkok:Thammasat University, 2016, Retrieved on 1st January 2021, from http://ethesisarchive.library.tu.ac.th/thesis/ 2016/TU_2016_5802030774_5181_3947. pdf

[15] Nisarat Chayannakorn and Pat Pattanarangsun, "Factors Affecting Customer Decision on Using the Premium Saving Bond Service at the Bank for Agriculture and Agricultural Cooperatives (BAAC), Laemchabang Branch", Academic Services Journal, Prince of Songkla University (ASJ-PSU]), Vol.30, No.3, pp.98-109, 2019.

[16] Alafeef, M., "The Influence of Service Marketing Mix on Customer Loyalty towards Islamic Banks: Evidence from Jordan", International Journal of Academic Research in Accounting, Finance and Management Sciences, Vol.10, No.3, pp.239-255, 2020.

[17] Jawdat Jaafar Khatab et al., "Dimensions of Service Marketing Mix and its Effects on Customer Satisfaction: A Case Study of International Kurdistan Banking Erbil City-Iraq", Journal of Test Engineering and Management, Vol81, pp.4846 - 4855, 2019.

[18] Abdul Ghafoor Awan and Maliha Azhar, "Consumer Behaviour Towards Islamic Banking in Pakistan", European Journal of Accounting Auditing and Finance Research Vol.2, No.9, pp.42-65, November 2014.

[19] Kamsol Mohamed Kassim et al. 2009. "Retaining Customers through Relationship Marketing in an Islamic Financial Institution in Malaysia". International Journal of Marketing Studies. Vol.1, No.1, pp. 66-71, May 2009.

[20] Nur Syamilah Md Noor and Hydzulkifli Hashim Omar., "The Relationship Marketing As A Determinant Of Customer Satisfaction In Islamic Banking Services Management", IJMS Vol.22, No.1, pp122 , 2015.

From 
http://repo.uum.edu.my/15246/1/ijms2211. pdf

[21] Ahmad, M.F et al., "The Effect of Demographics on Customer Satisfaction amongst Malaysia Hajj Pilgrims: Survey Result", Applied Mechanics and Materials Vol. 660, pp 1000-1004, 2014.

[22] Thipthingthae, Aurasa \& Vachungngern, Pipob, "Consumer Behavior Service Effect Marketing the Government Saving Bank Service in Pranburi District, PrachuapKhiri Khan Province", The Journal Of Faculty Of Applied Art, Vol 8, No. 1, pp.62-69, 2015.

[23] Lal, J., Vij, M., \& Jain, S., "Do Demographics Influence Customer Service Quality Perceptions: A Comparative Study of Indian and Foreign Banks", Journal of Services Research, Vol.14, No.2, pp.75105, 2014.

[24] Norma Md. Saad, "Comparative Analysis of Customer Satisfaction on Islamic and Conventional Banks in Malaysia", Asian Social Science, Vol. 8, No. 1, January 2012.

From http://ierc.sbu.ac.ir/File/Article/Comparati ve\%20Analysis\%20of\%20Customer\%20S atisfaction\%20on\%20Islamic_92914.pdf

[25] Rungroje Songsraboon, "Satisfaction On The Service Of Islamic Bank Of Thailand, Nontaburi Branch", Journal of Thonburi University, Vo.11, No.25, pp.6877, 2017.

[26] Kaewta Hunnala \& Chairirk Keawpromman, "Factors Influencing the Decision in Choosing Housing Loan Provided By TISCOBank in Bangkok Metropolitan and Vicinity", Journal of Interdisciplinary Research: Graduate Studies, Vol.8, No.2, pp.390-399, 2019.

[27] Meeduang, Suratda, "Factors Affecting Decision Making To Use Housing Loans In Bangkok: A Case Study Of Government Savings Bank, Ratchadamnoen Branch", Bangkok: Silpakorn University, 2016. Retrieved on 1st January 2021, from http://ithesis-

ir.su.ac.th/dspace/handle/123456789/269
[28] Arisara Hnwysangkhar, "The Factors that Affect Decision Making and Consumer behavior for using the services at Kasikornbank PCL.”, SSRU Journal of Public Administration, Vol.3, No.3, pp.1421, 2020. 